\title{
Cell-surface Hydrophobicity of Candida Species as Determined by the Contact-angle and Hydrocarbon-adherence Methods
}

\author{
By SHOGO MINAGI, ${ }^{\text {YOICHIRO MIYAKE, } 2 \text { YUMI FUJIOKA, }}$ \\ HIROMICHI TSURU' AND HIDEKAZU SUGINAKA ** \\ ${ }^{1}$ Department of Removable Prosthodontics and 'Department of Microbiology and Oral \\ Bacteriology, Hiroshima University School of Dentistry, Hiroshima 734, Japan
}

(Received 13 August 1985; revised 12 November 1985)

Cell-surface hydrophobicities of six Candida species were studied by two methods: measurement of the contact angle, and partitioning with aqueous-hydrocarbon (n-octane, nhexadecane and p-xylene) mixtures. $C$. tropicalis, $C$. glabrata and $C$. krusei adhered better to the hydrocarbons than did $C$. albicans, $C$. stellatoidea and $C$. parapsilosis. Contact angles for the less adherent species were smaller than those for the more adherent species. Thus the two methods gave results that were similar overall and indicated that $C$. tropicalis, $C$. glabrata and $C$. krusei have greater cell-surface hydrophobicities than $C$. albicans, $C$. stellatoidea and C. parapsilosis.

\section{INTRODUCTION}

Bacterial adherence to the surface of animal cells is an important step in the infection process (Ofek \& Beachey, 1980), and hydrophobic interactions are thought to be involved in the adherence of a variety of bacteria to host tissues (Miörner et al., 1983; Peres et al., 1977). To study microbial attachment to surfaces, a number of methods to evaluate cell-surface hydrophobicity have been developed (Lindahl et al., 1981; Jonsson \& Wadström, 1984). Contact-angle methods and partitioning methods with hydrocarbons have been used in many investigations (Miura et al., 1977; Iimura et al., 1980; Rosenberg et al., 1980; Busscher et al., 1984).

Gerson \& Scheer (1980) reported that adherence of bacteria to hydrophobic surfaces is affected by the change in interfacial free energy which corresponds to the process of attachment. In a previous report (Minagi et al., 1985), we described a physico-chemical mechanism for adherence of Candida to various resin surfaces. In the present study, we have investigated the adherence of six Candida species to three hydrocarbons (n-octane, $\mathrm{n}$-hexadecane and $p$-xylene). The cell-surface hydrophobicities of the organisms were also determined, by Young contactangle measurements, and results obtained by the two methods were compared.

\section{METHODS}

Candida strains and growth conditions. The organisms used were $C$. albicans IFO (Institute of Fermentation Osaka, Japan) 1385, ( . tropicalis IFO 1400, C. stellatoidea IFO 0692, C. parapsilosis IFO 1396, C. krusei IFO 1395 and $C$. glabrata IFO 0622 . The yeasts, maintained on slopes of Sabouraud glucose agar $[1 \%(\mathrm{w} / \mathrm{v})$ peptone, $0.5 \%$ $(w / v)$ yeast extract and $2{ }_{\circ}^{\circ}(w / v)$ glucose], were precultured in Sabouraud glucose broth at $37^{\circ} \mathrm{C}$ overnight. A $10 \mathrm{ml}$ portion of the preculture was inoculated in to $40 \mathrm{ml}$ Sabouraud glucose broth and incubated at $37^{\circ} \mathrm{C}$ with shaking to $\mathrm{OD}_{\text {bo }} 2.0$ (18 mm light path: Hitachi model $110-10$ spectrophotometer). Cells were harvested by centrifugation (Kubota model $\mathrm{KN}-70$ ) at $1500 \mathrm{~g}$ for $5 \mathrm{~min}$ at $20^{\circ} \mathrm{C}$, washed three times with $0.01 \mathrm{M}$-phosphate-buffered saline (PBS; $0.15 \mathrm{M}-\mathrm{NaCl}$ and $0.01 \mathrm{M}$-phosphate buffer, $\mathrm{pH} 7.3$ ) and resuspended in PBS.

Contact angle. To measure the Young contact angle of the yeasts, a layer of cells was prepared on a membrane filter (pore size $0.45 \mu \mathrm{m}$; Millipore) as previously described (Minagi et al., 1985), and air dried. The Young contact angle of distilled water on the yeast cell layer was measured by the horizontal-projection technique with a contact angle meter (Kyowa type CA-A) at $20^{\circ} \mathrm{C}$. Contact angles were measured at ten points on the yeast cell layer and the mean value was calculated. 
Adherence to hydrocarbons. The adherence of the yeasts to hydrocarbons was measured by the method described by Rosenberg et al. (1980). To round-bottomed test tubes ( $10 \mathrm{~mm}$ internal diameter) containing washed cells suspended in $3 \mathrm{ml}$ PBS and adjusted to an $\mathrm{OD}_{660}$ of approximately 0.5 were added various volumes $(0-0.5 \mathrm{ml})$ of $\mathrm{n}$ octane, $\mathrm{n}$-hexadecane or $p$-xylene (Katayama Chemical Industries $C o$.). The surface tensions of $n$-octane, $n$ hexadecane and $p$-xylene are $21 \cdot 7,27.7$ and $28.3 \mathrm{~mJ} \mathrm{~m}^{-2}$, respectively (Schäfer \& Lax, 1956). The mixtures were vigorously agitated for $60 \mathrm{~s}$ using a flat-top mixer (model MT-51 Touch Mixer; Yamato Scientific Co.). Immediately after separation of the two phases, the aqueous phase was carefully removed with a Pasteur pipette and transferred to a cuvette, and the $\mathrm{OD}_{660}$ was measured. Results were expressed as the percentage of the initial $\mathrm{OD}_{660}$ of the aqueous suspension as a function of hydrocarbon volume added.

Cell surface free energy. The surface free energy of a micro-organism ( $\gamma^{\text {NiV }}$ ) is given by equation (1) and some derivatives described by Neumann et al. (1974)

$$
\cos \theta=\frac{\left(0.015 \gamma^{M V}-2.00\right)\left(\gamma^{M V} \gamma^{L V}\right)^{1 / 2}+\gamma^{L V}}{\gamma^{L V}\left[0.015\left(\gamma^{M V} \gamma^{L V}\right)^{1 / 2}-1\right]}
$$

where $\theta$ is the Young contact angle of distilled water on the cell layer, and $\gamma^{\mathrm{L} Y}$ is the surface tension of distilled water.

\section{RESULTS}

Contact angle measurements. Table 1 shows the mean contact angle of distilled water for the six Candida species. C. tropicalis demonstrated the largest contact angle, and $C$. stellatoidea the smallest.

Adherence to hydrocarbons. The adherence of the six Candida species to n-hexadecane is shown in Fig. 1, and their adherence to $50 \mu \mathrm{l}$ and $500 \mu \mathrm{l}$ of three hydrocarbons is shown in Table 1 . These results demonstrate that $C$. albicans and $C$. stellatoidea show low adherence, whereas $C$. tropicalis, $C$. glabrata and $C$. krusei are highly adherent. Although $C$. tropicalis was the most adherent to $50 \mu \mathrm{ln}$-hexadecane, $C$. krusei had the highest affinity to $200-500 \mu \mathrm{l}$-hexadecane of the test strains.

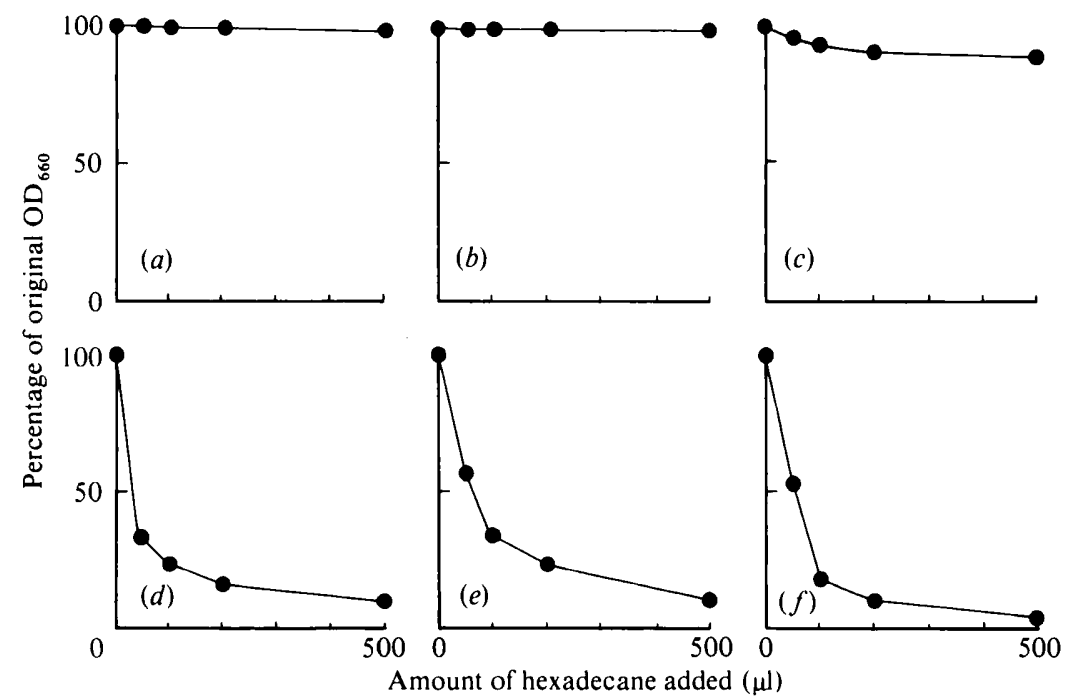

Fig. 1. Fractional decrease of $\mathrm{OD}_{660}$ of suspensions of Candida species as a function of hexadecane volume added. PBS suspensions of $(a) C$. albicans, (b) C. stellatoidea, (c) C. parapsilosis, (d) C. tropicalis, (e) $C$. glabrata and $(f) C$. krusei were used. The results are presented as the percentage $O_{b \circ 0}$ of the cell suspension after mixing with hexadecane, relative to that of the initial cell suspension. 


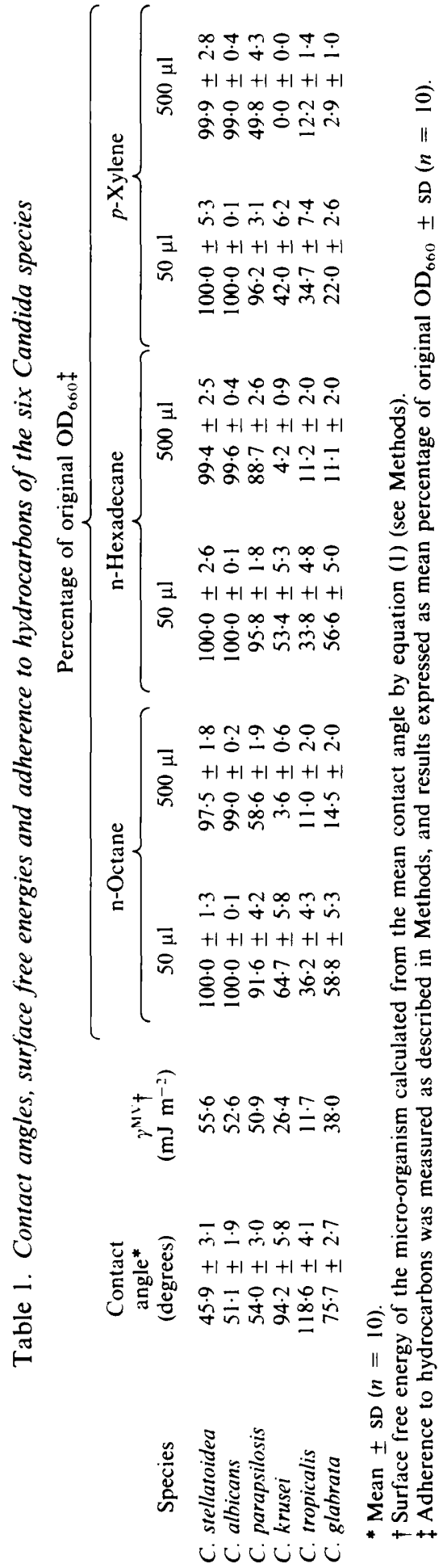


Cell-surface free energy. The surface free energies $\left(\gamma^{\mathrm{Mv}}\right)$ of the yeasts, calculated from the mean contact angles by equation (1), are shown in Table 1 . The calculated value of the surface free energy of $C$. tropicalis was the smallest and that of $C$. stellatoidea was the largest of the six species.

\section{DISCUSSION}

A number of methods to evaluate cell surface hydrophobicity have been developed; the twoliquid partition method with hydrocarbons has been used in many investigations (Rosenberg $e t$ al., 1980; Ofek et al., 1983; Gibbons et al., 1983). In a previous report, we described a physicochemical mechanism for adherence of Candida to various resin surfaces, and showed that the change in interfacial free energy, calculated from the contact angles of the resin surface and the yeast cell layer, correlated well with the adherence of the yeasts (Minagi et al., 1985). In the present study, we examined the relation between the contact-angle method and the partitioning method for evaluating yeast surface hydrophobicity.

The adherence of Candida species to n-octane, $\mathrm{n}$-hexadecane and $p$-xylene was examined with the partitioning method. C. tropicalis, $C$. glabrata and $C$. krusei adhered well to the hydrocarbons, while $C$. albicans, $C$. stellatoidea and $C$. parapsilosis were less adherent. The contact angles of the less adherent species were smaller than those of the more adherent species. Although the contact angles of the yeasts were measured on dry cell layers in the present study, measurements on moist bacterial layers have been reported (Busscher et al., 1984). In general, contact angles measured on dry layers are somewhat larger than those on wet layers. C. tropicalis showed the largest contact angle of the six species, 118.6 degrees (Table 1), a value similar to that reported for Streptococcus mitis L2 (111 degrees; van Pelt et al., 1984). Overall similarity of the results obtained from the partitioning method and the contact angle method on dry cell layers was demonstrated in the present study. However, a more accurate method of determining cellsurface hydrophobicity will be necessary for the exact physico-chemical analysis of yeast cell adherence.

\section{REFERENCES}

Busscher, H. J., Weerkamp, A. H., VAN der Mei, H. C., VAN Pelt, A. W. J., DE Jong, H. P. \& ARENDS, J. (1984). Measurement of the surface free energy of bacterial cell surfaces and its relevance for adhesion. Applied and Enironmental Microbiology 48, 980-983.

Gerson, D. F. \& Scheer, D. (1980). Cell surface energy, contact angles and phase partition. III. Adhesion of bacterial cells to hydrophobic surfaces. Biochimica et biophysica acta 602, 506-510

Gibbons, R. J., Etherden, I. \& Skobe, Z. (1983). Association of fimbriae with the hydrophobicity of Streptococcus sanguis FC-1 and adherence to salivary pellicles. Infection and Immunity 41, 414-417.

Iimura, Y., Hara, S. \& Otsuka, K. (1980). Studies on film yeasts of wine. Part III. Fatty acids as hydrophobic substance on cell surface of film strain of Saccharomyces. Agricultural and Biological Chemistry 44, 1223-1229.

JoNSSON, P. \& WADSTRÖM, T. (1984). Cell surface hydrophobicity of Staphylococcus aureus measured by the salt aggregation test (SAT). Current Microbiology 10, 203-210

Lindahl, M., FARIS, A., Wadström, T. \& HJerten, S. (1981). A new test based on 'salting out' to measure relative surface hydrophobicity of bacterial cells. Biochimica et biophysica acta 677, 471-476.

Minagi, S., MiYake, Y., Inagaki, K., Tsuru, H. \&
SuginaKa, H. (1985). Hydrophobic interaction in Candida albicans and Candida tropicalis adherence to various denture base resin materials. Infection and Immunity 47, 11-14.

Miörner, H., Johansson, G. \& Kronvall, G. (1983). Lipoteichoic acid is the major cell wall component responsible for surface hydrophobicity of group A streptococci. Infection and Immunity 39, 336-343.

Miura, Y., Okazaki, M., Hamada, S., Murakawa, S. \& YUGEN, R. (1977). Assimilation of liquid hydrocarbon by microorganisms. I. Mechanism of hydrocarbon uptake. Biotechnology and Bioengineering 19. $701-714$.

Neumann, A. W., Good, R. J., Hope, C. J. \& Sejpal, M. (1974). An equation-of-state approach to determine surface tensions of low-energy solids from contact angles. Journal of Colloid and Interface Science 49, 291-304.

Ofek, I. \& Beachey, E. H. (1980). General concepts and principles of bacterial adherence in animals and man. In Bacterial Adherence. (Receptors and Recognition, Series B, vol. 6), pp. I 31. Edited by F. H. Beachey. London \& New York: Chapman \& Hall

Ofek, I., Whitnack, E. \& Beachey, E. H. (1983). Hydrophobic interactions of group A streptococci with hexadecane droplets. Journal of Bacteriology 154, 139-145. 
van Pelt, A. W. J., van der Mei, H. C., Busscher, H. J., ARENDS, J. \& WEerkamp, A. H. (1984). Surface free energies of oral streptococci. FEMS Microbiology Letters 25, 279-282.

Peres, L., Andaker, L., Edebo, L., Stendahl, O. \& TAGESSON, C. (1977). Association of some enterobacteria with intestinal mucosa of mouse in relation to their partition in aqueous two-phase systems. Acta pathologica scandinatica B85, 308-316.
Rosenberg, M., Gutnick, D. \& Rosenberg, E. (1980). Adherence of bacteria to hydrocarbons: a simple method for measuring cell-surface hydrophobicity. FEMS Microbiology Letters 9, 29-33.

SCHÄFER, K. \& LAX, E. (1956). Schmelzgleichgewichte und Grenzflächenerscheinungen. In Landolt-Bornstein, 6th edn, II. Band, 3. Teil, pp. 420-425. Heidelberg: Springer-Verlag. 